\title{
Adolessente se ervaring binne 'n lesbiese ouerhuis: 'n Pastorale-Gestaltteoretiese hulpverlening
}

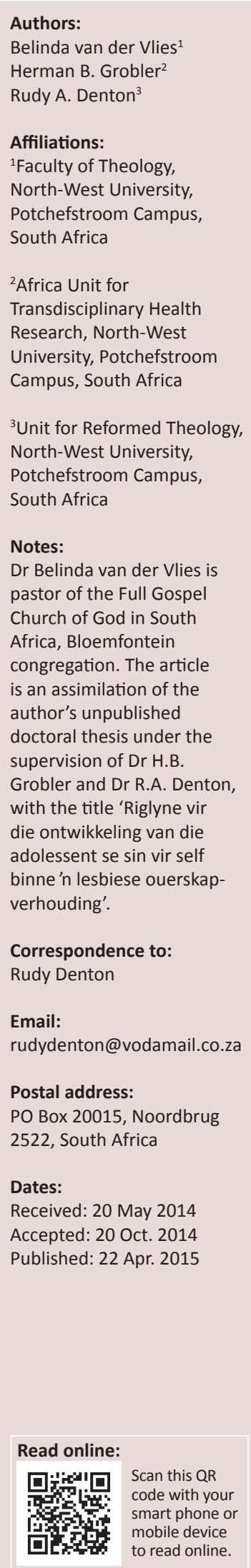

The article describes the development of adolescents for a sense of self in a lesbian home, in order to compile guidelines for lesbian parents as well as pastoral counsellors to help and guide adolescents to develop a healthy sense of self. From the research results, it appears that there are certain positive and negative aspects of a lesbian home that influence adolescents' sense of self. Where both parents are involved with the adolescents, share household duties equally and have a quality relationship with each other and the adolescents, the adolescents are generally well-adapted, happy and able to handle challenges in order to develop a healthy sense of self. The positive influence that Christian religious certainty has on the overall development of the adolescents was also confirmed by this study. On the other hand, adolescents experience particular aspects as challenging and impeding in their development of a healthy sense of self: Conflict and criticism from the companion parents are humiliating and destructive. Stigmatising, teasing and rejection from the hetero-normative society, as a result of their parents' sexual orientation, appear to be the largest obstacles in their psychosocial development. They react in a shy, negative and evasive way to the stigmatisation and withdraw themselves from situations that could be painful and humiliating. It also appears that the absence of a father figure and financial tension in lesbian families are impeding the adolescents' healthy development of a sense of self.

\section{Inleiding}

Binne die postmoderne era dring die besef al meer en meer deur dat die huwelik en gesin, soos wat dit tradisioneel verstaan word, onder geweldige druk verkeer (Dreyer 2007:625; Horak 2005:39). Volgens Dreyer (2008:483) en Van Wyk (2002:265) het daar in die afgelope vier dekades ' $n$ ingrypende verandering plaasgevind in bestaande familiepatrone in die Westerse wêreld. Hierdie veranderings word weerspieël in die stygende egskeidingsyfer, buite-egtelike geboortes, gay huwelike en saamwoon verhoudinge. Duisende kinders word jaarliks hierdeur geraak (Ebersohn 2001:41). Volgens verskeie navorsers (Taljaard \& Langner 2013:3 van 18; Barna 2011b:43; Barna 2011a:3; Van Niekerk 2005:1) het die bogenoemde tendense die postmoderne gesin in die Westerse samelewing in 'n krisis gedompel. Volgens Van Niekerk (2005:1) word die problematiek hoofsaaklik beskou vanuit die verandering van die kerngesin waarvan die pa dikwels afwesig is.

Daar bestaan egter steeds uiteenlopende teorieë rakende die nadele van gesinne wat nie uit twee heteroseksuele ouers bestaan nie. Die doel van hierdie artikel is om krities te vra na die ervaring van adolessente binne ' $n$ lesbiese ouerhuis en hoe lesbiese ouerskap-gesinne adolessente se ontwikkeling van 'n sin vir self raak. Die onderwerp is vanuit sowel 'n pastorale basisteorie (normatiewe perspektief) as 'n Gestaltteoretiese perspektief (paradigmatiese perspektief) bestudeer. ' $n$ Kwalitatiewe benadering is vir die doel van hierdie studie gevolg, met semigestruktureerde onderhoudvoering met onderskeidelik die adolessente en hul ouers.

\section{Die lesbiese ouerhuis}

Een van die belangrikste veranderinge wat die moderne gesin ondergaan het, is die verandering in gesinstrukture (Kottak 2010:290, 2008:409; Larney 2009:59; Lamanna \& Riedmann 2009:14). Die kerngesin is tradisioneel beskou as 'n gesin wat bestaan het uit 'n werkende vader, 'n tuisteskeppende moeder en afhanklike kinders (Kottak 2010:287, 2008:410; Maré 1996:6). Binne hierdie konvensionele kerngesin het daar duidelike grense bestaan tussen die private en die openbare, tussen huis en werk en tussen ouers en kinders. Daar

How to cite this article: Van der Vlies, B., Grobler, H.B., Denton, R.A., 2015, 'Adolessente se ervaring binne ' $n$ lesbiese ouerhuis: 'n Pastorale-Gestaltteoretiese hulpverlening', HTS Teologiese Studies/Theological Studies 71(1), Art. \#2735, 10 pages. http://dx.doi. org/10.4102/hts.v71i3.2735

Copyright: @ 2015. The Authors. Licensee: AOSIS OpenJournals. This work is licensed under the Creative Commons Attribution License. 
was ook duidelike grense betreffende die geslagtelike rolle wat die onderskeie ouers vervul het. Die vader is beskou as die gesagdraende party in die gesinseenheid. Sy gesag is as absoluut en beslissend beskou (Larney 2009:59; Maré 1996:4; Strydom 2001:54).

Die postmoderne gesin, daarteenoor, is baie meer vloeibaar en aanpasbaar en blootgestel aan druk van buite (Balswick \& Balswick 2006:187). Volgens Lamanna en Riedmann (2009:11) hou die postmoderne wêreld 'n groot verskeidenheid van verskillende gesinstrukture voor en individue kan self ' $n$ keuse uitoefen in watter strukture hulle hulself gemaklik vind. Binne hierdie denkraamwerk kan elkeen wat hom of haarself in 'n primêre groepering bevind, daarin lewensvervulling vind, daardie groepering funksioneel ervaar vir die uitlewing van persoonlike behoeftes, en na die groepering as gesin verwys (Müller 2002:13; Strong, De Vault \& Cohen 2011:11; Thatcher 2007:9). In hierdie verband wys Du Plessis (2009:254) daarop dat soveel as dertig verskillende gesinsvorme voorkom.

Amoateng et al. (2004:1) verwys na die volgende strukture wat net voorkom binne die sogenaamde saamgestelde gesin. Daar kan onderskei word tussen:

- 'n man met kinders wat trou met 'n vrou (wat nog nooit getroud was nie) sonder kinders

- 'n vrou met kinders wat trou met 'n man (wat nog nooit getroud was nie) sonder kinders

- 'n geskeide vrou met kinders wat trou met 'n geskeide man met kinders

- 'n wewenaar en weduwee met kinders wat hertrou

- geskeide ouers of ouers wie se eggenoot oorlede is, wat trou en waarvan hul kinders reeds volwasse is.

Binne die Westerse wêreld kan 'n groot verskeidenheid gesinstrukture onderskei word, byvoorbeeld enkel-ouer gesinne, tradisionele gesinne (pa, ma en kinders), lede van dieselfde geslag wat kinders aanneem en 'n gesin vorm, kinders wat deur grootouers grootgemaak word en nog vele meer (Du Plessis 2009:254).

Uit die voorafgaande bespreking blyk dit dat die lesbiese ouerhuis ook een van die vele gesinsvorme is wat binne die postmodernistiese klimaat gebore is. Die toekoms van die postmoderne gesinne word nie rooskleurig geskets nie, maar daar word eerder na 'n morele en gesinskrisis verwys, wat aandag en bespreking op die hoogste politieke, kerklike, opvoedkundige en sosiale vlak van die samelewing ontlok (Joubert 2009:28; Van Niekerk 2005:51; Wogaman 2009:83). Die krisis binne die gesin word hoofsaaklik vanuit die verandering van die struktuur van die gesin waarin pa's al hoe meer afwesig word, gesien (Jordaan 2005:103; Pleck \& Masciadrelli 2004:258). Die afwesigheid van die vaderfiguur dra nie by tot die fisieke, emosionele en geestelike welsyn van kinders nie, en derhalwe hou die sosiale wetenskappe die afwesige vaderfiguur voor as die sleutelrolspeler in die postmoderne gesinskrisis (Barna 2011a:44; Jordaan 2005:104; Van Niekerk 2005:51).
Binne die lesbiese ouerhuis is die afwesigheid van 'n vaderfiguur 'n brandende knelpunt. Vanuit die navorsing is dit duidelik dat die invloed van die postmodernisme op die gesin 'n beroep doen op die samelewing tot diepe nadenke en verantwoordelike besluitneming en optrede (De Villiers 2007:120). Johnson en O'Conner (2001:146) wat die boek, For lesbian parents, vanuit hul persoonlike ervaring as lesbiese ouers geskryf het, erken dat die afwesigheid van die vaderfiguur in die lesbiese ouerhuis 'n belangrike knelpunt is. Johnson en $\mathrm{O}^{\prime}$ Conner (2001:146) meen in hierdie verband: 'No matter how many males are in your child's life, no matter how many grandfathers, uncles, godfathers, troop leaders, whatever, there is no father living in the house.' Die afwesigheid van die man as vaderfiguur het kommerwekkende gevolge op die totale ontwikkeling en welsyn van kinders (Barna 2011a:34; Jordaan 2005:135; Stanton \& Maier 2005:135; Van Niekerk 2005:3). Stoop (2004) beskryf die volgende belewenisse van adolessente waar die vaderfiguur in die adolessente stadium afwesig was.

Die verskillende moontlike belewenisse van dogters is:

- Hulle is geneig tot eetversteurings soos anoreksie en bulimie.

- Die moontlikheid van die skyn van vroegtydige en onnatuurlike volwassenheid waarin hulle volwasse gedrag openbaar, maar innerlik verward en onvolwasse is.

- Hulle kan vrese ten opsigte van hul seksualiteit ontwikkel, wat tot die onderdrukking van seksuele gevoelens of die uitleef daarvan met mansfigure op 'n naïewe wyse kan lei.

- Die voorkoms van depressie, jeugmisdaad, skolastiese probleme en vatbaarheid vir groepsdruk.

- Tipiese romantisering en idealisering van die afwesige pa kan voorkom; iets waarmee geen ander mansfiguur kan kompeteer nie.

- Die seën van die vader bly 'n hunkering wanneer hulle die oorgang van adolessensie na volwassenheid bereik (Stoop 2004:133-141).

Die volgende is moontlike belewenisse wat seuns ervaar:

- Hulle voel ontmoedig om sonder die aanmoediging van die pa's, aan sosiale aktiwiteite soos sport, kultuur en ontspanning deel te neem, wat aanleiding gee tot ontrekkendegedrag. Ditkan totdwelm-enalkoholmisbruik, kompulsiewe dobbelgewoontes, seksuele promiskuïteit en ' $n$ algemene ervaring dat hulle nie invoeling met hul emosies is nie, lei.

- Die ervaring van onvermoë om sukses by die skool of die werk te behaal.

- Die voorkoms van die lewenslange adolessent, en optrede soos 'n tiener met betrekking tot sport, seks of hoë risiko aktiwiteite.

- 'n Ervaring van onvermoë om hulle aan 'n vrou te verbind, omdat hulle bevrees is dat sy beheer sal verkry of hul keuses sal beperk.

- Hulle kan 'n stryd teen gesag en gesagsfigure voer. Hulle kan oorwegend passiewe, passief-agressiewe of rebellerende gedrag toon. 
- Hulle ervaar 'n onvermoë en hunkering na die seën van die vader met die oorgang van adolessensie na volwassenheid (Stoop 2004:133-141).

Volgens Stoop (2004:133-141) spreek hierdie belewenisse vanself dat die afwesigheid van die vaderfiguur noodlottige gevolge in gesinne kan aanneem en 'n besliste kwelpunt ten opsigte van die lesbiese ouerhuis is. Marks (2012:745) en Perlesz en McNair (2004:135) wys verder daarop dat daar 'n groot uitdaging aan lesbiese ouers gestel word om binne 'n heteroseksuele samelewing met bepaalde voorbehoude en kritiek, 'n gesinsomgewing te skep waarin kinders en adolessente kan grootword en 'n gesonde identiteit, selfbeeld en sin vir self kan ontwikkel. Volgens Telingator en Patterson (2008:1367) kan hulpverleningsprofessies 'n groot rol speel en ' $n$ bydrae lewer om lesbiese gesinne te ondersteun, by te staan en te help om hul ervaringe te deel, hul uitdagings te bespreek en hul probleme te oorkom, ten einde 'n omgewing te skep waarin hul kinders maksimaal kan groei en ontwikkel.

\section{Adolessente se ontwikkeling van die sin vir self}

Identiteitsvestiging word as een van die belangrikste ontwikkelingstake van adolessensie gesien, aangesien adolessente gekonfronteer word met die verantwoordelikheid om hulself as't ware te vind, asook om te besluit watter rol hulle in die samelewing gaan vervul (Beyers 2005:6). Woodward (2002) benadruk die feit dat identiteitsontwikkeling binne ' $n$ spesifieke omgewing of veld plaasvind en beskryf dit soos volg:

Who am I? It looks like a question that cannot be answered without some reference to you, us and them; to the other people with whom I have contact. Who I am is closely interwoven with ideas about the society in which I live and the views of others who also inhabit that same social context. Identity matters, but how and why it matters depends on time and place and on specific historical, social and material circumstances. (bl. 1)

Warnke (2007:245) sluit hierby aan wanneer hy daarop wys dat identiteit deel vorm van 'n spesifieke konteks en dat identiteit dus net verstaan kan word as deel van die spesifieke konteks. Volgens Peacock en Theron (2007) kan identiteit soos volg beskryf word:

The concept identity is derived from the Latin word idem which means the same. It refers to the ability of an object to remain consistent or to form unity, or as in the case of the adolescent, uniqueness and sameness. The actual process of identity achievement is a multifaceted configuration of social and self representations. (bl. 62)

Identiteit verwys na die individu se bewustheid van hom of haarself as 'n onafhanklike, unieke persoon met 'n spesifieke lewensdoel en bepaalde plek in die samelewing (Louw, Van Ede \& Louw 2004:429). Sigelman en Rider (2009:325) wys op hul beurt weer daarop dat identiteit nie 'n gegewe is nie. Adolessente moet die hulpbronne tot hul beskikking en hul unieke risikofaktore evalueer ten einde dit suksesvol aan te wend in die vorming van 'n unieke identiteit
(Van Wyk 2011:61). Erikson (1982:17) sluit by hulle aan wanneer hy meen dat 'n geïntegreerde identiteit nie sonder moeite en deelname aan die kant van die adolessent verkry kan word nie.

Adolessente se evaluering van die self, persoonlike kwaliteite, sterktes en talente staan sentraal in hul ontwikkeling van 'n sin vir self (Shaffer \& Kipp 2007:475). Die sin vir self beïnloed al die aspekte van adolessente se ontwikkeling en hul psigologiese welstand (Henderson \& Thompson 2011:45). Adolessente se ontwikkeling van 'n sin vir self beïnvloed ook hul identiteitsontwikkeling. Namate hul sienings, beskrywings en definiëring van die self verander, word hul eie uniekheid bevestig en stel dit hulle in staat om 'n persoonlike identiteit te bereik (Louw et al. 2004:437).

Die sin vir self verwys na adolessente se algehele evaluasie van die self en sluit gevoelens van geluk, tevredenheid en selfaanvaarding in (Manning 2007:11). Adolessente evalueer hulself vanuit verskillende dimensies, soos vanuit hul gesinne, hegte vriendskappe, romantiese verhoudings, akademiese prestasies en toekomsverwagtinge, wat hul uiteindelike sin vir self voorafgaan en bepaal (Berk 2012:602). Volgens Whitney-Thomas en Moloney (2001:377) is adolessente se ontwikkeling van 'n sin vir self 'n komplekse proses van introspeksie, evaluering van besluite wat hulle geneem het, foute wat hulle gemaak het en die voortdurende beoordeling van hul interaksie met die belangrike ander in hul lewens. Shaffer en Kipp (2007:475) sluit hierby aan en meen dat die komplekse proses van die ontwikkeling van 'n gesonde sin vir self en 'n gevoel van selfwaarde reeds tydens die babajare begin en grootliks beïnvloed word deur die gehegtheidsbande wat daar tussen die baba en sy of haar primêre versorger gesluit word. Oaklander (1988) beskryf die invloed van gehegtheidsbande en die ouer-kind-verhouding op die ontwikkeling van ' $n$ sin vir self soos volg:

A Baby is not born with bad feelings about himself. All babies think they are wonderful. How a child feels about himself after a time, however, is certainly determined to a great extent by the early messages he gets about himself from his parents. In the final analysis though, it is the child himself who translates those messages to himself. (bl. 280)

Hoewel die sin vir self ontwikkel vanaf geboorte, bereik dit ' $n$ kritieke periode tydens adolessensie as gevolg van adolessente se toenemende kognitiewe vermoëns (Kiesling et al. 2006:256). Adolessente se vermoë om hipotetiesdeduktief te redeneer, stel hulle in staat om bestaande sosiale stelsels en beskouings krities te evalueer ten einde hul eie opinie daaroor te konstrueer (Louw et al. 2004:429). Deur die kritiese ondersoek en evaluering van sosiale waardes, norme, sienings en rolle, vorm adolessente hul persoonlike teorieë rakende belangrike aspekte soos hul gesinne, die samelewing en wêreldbeskouinge (Berger 2011:414; Bosacki \& Ota 2000:209). Bosacki (2001:211) is van mening dat adolessente hul eie teorieë, beskouinge en denke toets, ontwikkel en verfyn deur dit in hul eie lewensverhale oor te vertel binne hul gesinne, portuurgroep en breër sosiale omgewing. Deur die vertel en oorvertel van hul lewensverhale, word 
adolessente toenemend bewus van hulself (Bosacki 2001:211; Bosacki \& Ota 2000:209).

\section{Adolessente se toenemende selbewustheid}

Adolessente se toenemende selbewustheid word veral beïnvloed deur hul sensitiwiteit vir ander persone se siening, opinie en evaluering van hulself (Shaffer \& Kipp 2007:476). Hul selfwaarde word grootliks bepaal deur die boodskappe wat hulle uit die sosiale omgewing ontvang met betrekking tot hul voorkoms, vermoëns, prestasies en gewildheid (Berger 2011:439-444). Volgens Blom (2004:113) stel die evaluering van die self, wat plaasvind deur persoonlike ondersoek en evaluasie asook deur evaluasie en beoordeling van ander, die adolessent in staat om onderskeid te tref tussen die aspekte wat deel uitmaak van die self en die aspekte wat nie deel vorm van die self nie. Sodoende onderskei adolessente, deur 'n komplekse proses van interaksie tussen die self en sosiale omgewing of veld, die self van die eksterne omgewing of veld (Blom 2004:113).

Louw et al. (2004) meen dat die komplekse proses van selfbeoordeling aanleiding gee tot die volgende veranderinge in adolessente se selfbeskrywing:

- Adolessente fokus al hoe meer op psigiese eienskappe en minder op fisiese eienskappe in hul selfbeskrywings.

- Hulle beskrywings van die self raak minder konkreet en meer abstrak, soos byvoorbeeld: 'Ek is gemotiveerd' of 'Ek is liberaal'.

- Met adolessente se toenemende bewustheid van ander se opinies oor hulself, sluit hul selfbeskrywings al hoe meer van hul eie sosiale vaardighede in.

- Adolessente is ook in staat om 'n meer geïntegreerde en samehangende beskrywing van die self te gee as jonger kinders (bl. 438).

Volgens Neff en Mcgehee (2009:225) gee die veranderinge in adolessente se selfevaluering en die kompleksiteit van die vorming van 'n gesonde sin vir self dikwels aanleiding tot emosionele probleme tydens adolessensie. Adolessente ervaar intense druk om akademies te presteer, fisies aantreklik te wees, aanvaar te word deur die regte portuurgroep en die regte moreel-etiese besluite te neem. Hierdie druk gee dikwels aanleiding tot negatiewe selfevaluasie en 'n lae selfbeeld (Impett et al., 2008:723; Neff \& Mcgehee 2009:225; Whitney-Thomas \& Moloney 2001:377). 'n Lae selfbeeld en negatiewe sin vir self word verbind met emosionele toestande soos depressie, angs, selfbeserende gedrag en selfs selfmoord (Berk 2012:602). Die ontwikkeling van 'n gesonde sin vir self word verder beïnloed deur sosiale faktore soos gewildheid, prestasies en aanvaarding aan die een kant, en stigmatisering, verwerping en afkeur deur die portuurgroep aan die ander kant (Impett et al. 2008:724).

Wanneer die kompleksiteit van die ontwikkeling van die sin vir self en al die aspekte wat 'n invloed daarop uitoefen in oënskou geneem word, kan gesê word dat, solank as wat mense lewe, hulle gevorm word (Bosacki 2001:218). Mense leer van hul liggame, hul emosies, hul bewustheid en hul ervaring, en deur hierdie leerproses word die sin vir self gevorm en geslyp deur die lewe in geheel (Bosacki 2001:218). In hierdie verband meen Van Gelderen (2012:21 van 136) dat sosiale stigmatisering en homofobie 'n besliste invloed uitoefen op adolessente in lesbiese ouerhuise se ontwikkeling van 'n gesonde sin vir self en die bereiking van 'n persoonlike identiteit. Vir die gesonde ontwikkeling van die sin vir self, is dit egter nodig dat adolessente se bewustheid verhoog word, sodat hulle kan fokus op alle aspekte wat die leerproses kan bevorder of strem (Bosacki 2001:219). Volgens Blom (2004:113) kan adolessente met 'n gesonde sin vir self se bewustheid in die hier en nou hulle in staat stel om selfs foute en teleurstellings te beskou as geleenthede waaruit hulle kan leer en groei.

Adolessente se maatstawwe vir aantreklikheid, gewildheid, moraliteit, godsdiens en lewensbeskouings word geslyp in hul ouerhuise. Hul optredes is 'n vertoonvenster van hul ouerhuise wat oorvloei na elke aspek van adolessensie en uiteindelik ' $n$ bepalende rol speel in die wyse hoe adolessente na hulself, ander en die wêreld kyk. Louw (2005:714) bevestig hierdie mening en benadruk die belangrikheid van die gesin as onmiddellike omgewing van adolessente waar hulle hulself evalueer en hul sin vir self vorm.

In hierdie verband wys Coleman en Hagell (2007:21) daarop dat ouers in die postmodernistiese tydvak begeer om groter vryheid te geniet ten opsigte van gesinskeuses, gesinsamestellings en die uitleef van hul seksualiteit, terwyl adolessente hul behoeftes na gesinstabiliteit en konstante rolmodelle in die gesin bekend maak. Oswald en Kuvalanka (2008:1052) en Robitaille en Saint-Jacqeus (2009:432) sluit hierby aan in hul navorsing oor lesbiese ouerskap, en wys daarop dat hoewel kleiner kinders nie probleme ervaar met hul ouers se seksuele oriëntasie nie, adolessente en jong volwassenes dit wel problematies vind. Adolessente en jong volwassenes uit lesbiese ouerhuise meld dat hulle alles in hul vermoë sal doen om die seksualiteit van hul ouers 'n geheim te hou, veral om sosiale stigmatisering te voorkom (Robitaille \& Saint-Jacqeus 2009:432).

Collins (2005:330) noem dat die openheid wat rondom homoseksuele oriëntasie heers wel sekere persone tot die gevolgtrekking laat kom dat homoseksualiteit nie alleenlik 'goed' is nie, maar dat dit hulle nie minderwaardig teenoor persone met 'n heteroseksuele oriëntasie behoort te laat nie. Volgens Collins (2005:330) ervaar die meerderheid persone met 'n homoseksuele oriëntasie egter nog steeds skuldgevoelens oor hul homoseksuele neigings en gedrag; hulle voel verwerp en eensaam in 'n oormeerderheid heteroseksuele samelewing, hulle ervaar dikwels gevoelens van hopeloosheid en innerlike gevoelens van woede en gebrekkige eiewaarde. Sulke ervarings kan egter 'n patroon van sosiale of emosionele onttrekking en depressie skep. Die moontlikheid van verwerping word net nog groter en dit weerhou persone met 'n homoseksuele oriëntasie daarvan om hul eie gevoelens of identiteit aan te toon (Omoto \& Kurtzman 2006:245; Anthonissen \& Oberholzer 2001:157). 
Terwyl lesbiese ouers die bogenoemde emosies ervaar, word hul adolessente ook outomaties aan al die vraagstukke, uiteenlopende kommentaar en kritiek blootgestel, en hulle moet dieselfde emosionele prosesse deurwerk ten einde hulself te definieer in ' $n$ heteronormatiewe samelewing (Švab 2007:53). Berk (2012:553) wys daarop dat adolessente wat in groot stede woon, maklik groepe kan vind wat soos hulself uit lesbiese ouerhuise kom, maar in plattelandse omgewings is dit egter baie moeilik en in sommige gevalle onmoontlik. Hierdie adolessente hunker dan na ondersteuningstelsels wat hulle sal verstaan en kan begelei na sosiale en selfaanvaarding (Van Gelderen 2012:22 van 136). Uit die bespreking blyk dit dat, hoewel die gesin 'n bepalende rol speel in die identiteitsontwikkeling van die adolessent, die invloed van die wyer sosiale omgewing nie onderskat en buite rekening gelaat kan word nie (Berk 2012:553; Beyers 2005:10).

\section{Adolessente se ervaring binne ' $n$ lesbiese ouerhuis \\ Unieke gesinsfunksionering en gesinsverhoudinge}

Navorsingsbevindinge, vanuit die semigestruktureerde onderhoude met onderskeidelik die adolessente en hul ouers, dui daarop dat, net soos in die geval van heteroseksuele gesinne, daar beduidende verskille in die funksionering van lesbiese gesinne is. Die gesinsfunksionering word hoofsaaklik bepaal deur die rolle wat deur die lesbiese ouers aangeneem word. In die gesinne waar beide die lesbiese ouers betrokke is by die opvoeding van die adolessente, hul huishoudelike pligte eweredig verdeel en medeverantwoordelikheid vir ouerskap aanvaar, blyk die uitkomste vir die adolessente se algehele ontwikkeling die beste te wees. Die teendeel geld vir gesinne waar die lesbiese metgesel ouer haarself onttrek, antagonisties teenoor die adolessente optree en voortdurend in konflik met die adolessente betrokke raak. Hierdie negatiewe verhoudings lei daartoe dat adolessente onttrek uit gesinsaktiwiteite, hul vrymoedigheid binne die gesin verloor en gevoelens van alleenheid, frustrasie en onbevoegdheid ervaar, wat hul ontwikkeling van 'n gesonde sin vir self nadelig beïnvloed.

Die kwaliteit van die gesinsverhoudinge is dus ' $n$ belangrike bepaler van die adolessente se psigologiese welstand en hul ontwikkeling van ' $n$ sin vir self. Wanneer adolessente egter geliefd, veilig en aanvaar voel binne hul lesbiese ouerhuis, lê hulle die waagmoed aan die dag om hulself te wees en maksimaal te ontwikkel. Die navorsing het getoon dat adolessente binne positiewe gesinsfunksionering en gesinsverhoudinge die stigmatisering en verwerping vanuit die sosiale veld ook beter kan hanteer en oor die algemeen gesonde ontwikkeling van die sin vir self toon.

\section{Die adolessent se omskrywing van die self}

Vanuit die semigestruktureerde onderhoude met die adolessente het dit ook geblyk dat die adolessente in staat was om hulself te omskryf aan die hand van persoonlikheid, belangstellings, talente en gesins- en sosiale verhoudinge. Dit het duidelik na vore gekom dat die adolessente noukeurige introspeksie doen ten einde hulself te posisioneer en te onderskei binne ' $n$ oorheersend heteronormatiewe samelewing of veld. Die uitkomste van die selfondersoek was uiteenlopend. Die meerderheid adolessente het verkies om hul gesinsidentiteit 'n geheim te hou. Dit het verskeie gevolge rakende hul vriendekring, sosiale aktiwiteite en hul ouers se betrokkenheid by hul skole. Hoewel die meerderheid adolessente probeer om 'n baie positiewe beeld van hulself binne hul gesin en sosiale omgewing voor te hou, was dit duidelik dat hul vrees vir verwerping en stigmatisering hulle noodsaak om hanteringsmeganismes aan te leer om hulself te beskerm.

Vanuit die semi-gestruktureerde onderhoude het die aangenome adolessente egter die beste aangepas in hul lesbiese ouerhuis en hulle was nie skaam om hul gesinsidentiteit bekend te maak nie. Tasker en Patterson (2007:18) bevestig dat aangenome adolessente beter aanpas in lesbiese ouerhuise as adolessente wat na die egskeiding van hul heteroseksuele ouers saam met hul biologiese ma deel word van 'n lesbiese gesin. Laasgenoemde adolessente moet nie alleen aanpas by 'n lesbiese gesin nie, maar moet ook die trauma en krisisse van die egskeiding hanteer en deurworstel.

Die navorsing het ook gevind dat die adolessente bewus was van hul persoonlike besluitneming rakende verskillende aspekte van die lewe, insluitend hul lesbiese ouerhuis. Die adolessente het groot klem geplaas op die verantwoordelikheid wat individue vir hul eie keuses moet aanvaar. In hul groei na onafhanklikheid blyk dit dat hulle hulself posisioneer binne ' $n$ heteronormatiewe samelewing op grond van hul eie gedagtes, gevoelens en belewenisse binne hul lesbiese ouerhuis en die verwagtinge van die sosiale konteks waarbinne hulle hulself bevind. Sodoende toon die adolessente, wat aan die studie deelgeneem het, respek vir hul ouers se keuse om homoseksueel te wees, sonder om dit noodwendig goed te keur of te internaliseer. Hul persoonlike ervaring stel hulle in staat om die positiewe en negatiewe aspekte van hul unieke gesinsdinamika te onderskei en te bespreek.

\section{Faktore wat die sin vir self beïnvloed}

Adolessente se sin vir self word onder andere gevorm deur hul interaksie met hul direkte familie en breër sosiale omgewing. Binnehierdie verhoudingskonteks is daar verskeie faktore wat adolessente se sin vir self beïnvloed. Adolessente vra dikwels vrae soos: 'Is ek goed genoeg?', 'Wat dink ander mense van my?' en 'Is ek so goed soos my portuurgroep?' Adolessente wat in lesbiese ouerhuise grootword, word direk en indirek blootgestel aan antagonisme, stigmatisering, verwerping en homofobie ten opsigte van hul ouers se seksuele oriëntasie. Hierdie blootstelling lei tot die ontstaan van vrese vir spot en verwerping, wat emosionele druk op die adolessente plaas. Om hulself te beskerm, hou die adolessente hul gesinsidentiteit ' $n$ geheim en probeer hulself so min moontlik 
blootstel aan situasies waarin hulle verneder kan word (Tasker \& Patterson 2007:19). Vanuit die semigestruktureerde onderhoude is gevind dat die adolessente verkies om binne die portuurgroep net een of twee vriendskappe te sluit met vriende wat hulle kan vertrou. Hierdie vertrouelinge is ook die enigste vriende wat hulle sal oornooi na hul ouerhuise, of aan wie hulle hul gesinsidentiteit sal bekend maak.

Die druk wat deur die meeste adolessente ervaar word ten opsigte van hul ouers se seksuele oriëntasie, binne 'n oorwegend heteroseksuele samelewing, was vir hulle problematies. Dit bring emosies van vrees, angs en spanning teweeg. Dit blyk egter dat hulle hierdie druk beter kon hanteer en dat hulle positiewer oor hulself begin dink het nadat hulle Christelike geloofsekerheid verkry het. Dit onderskryf vorige navorsing van Boshoff (2002:9), Müller (2002:92) en Pienaar (2002:97) dat Christelike geloofsekerheid 'n positiewe bydrae tot die algehele ontwikkeling en psigologiese welstand van adolessente lewer. Christelike geloofsekerheid lei die adolessente tot 'n diepe verstaan van die self, die sin van die lewe en ander. Die feit dat adolessente hulself beter kan verstaan, sosiale en persoonlike druk kan hanteer en beter kan deel met spot en stigmatisering, vanuit 'n geloofsekere lewe, stel hulle in staat om 'n positiewe sin vir self te ontwikkel binne hul unieke omstandighede. Geloof is dus as 'n belangrike determinant vir die ontwikkeling van identiteit by adolessente binne 'n lesbiese ouerhuis gevind.

\section{Positiewe aspekte van die lesbiese gesin wat adolessente se sin vir self kan bevorder}

Vanuit die navorsing en literatuurstudie is gevind dat daar twee hoofstrome oor lesbiese ouerskap en die ontwikkeling van kinders en adolessente in hierdie ouerhuise bestaan. Aan die eenkant is daar homoseksuele aktiviste wat die regte van lesbiese ouers wil beskerm, en al hul navorsing toon net positiewe uitkomste vir kinders en adolessente wat by lesbiese ouers grootword (Švab 2007:49; Perlesz \& McNair 2004:134). Aan die ander kant is dit 'anti-gay' navorsers wat weer die klem plaas op uitsluitlik die negatiewe uitkomste vir kinders en adolessente wat by lesbiese ouers grootword (Johnson \& O'Connor 2001:146). Aan die einde van die navorsing het dit steeds geblyk dat daar 'n groot tekort aan objektiewe navorsing in verband met die algehele ontwikkeling van kinders en adolessente wat by lesbiese ouers grootword bestaan. Die doel van die navorsing was om 'n positiewe bydrae te lewer deur sowel die positiewe aspekte van lesbiese ouerskap as die negatiewe aspekte te verlig.

Vanuit die empiriese resultate van die navorsing het die adolessente die kwaliteit van hul gesinsverhouding as 'n sterkte van hul lesbiese gesin voorgehou. Dit geld vir die gesinne waar beide die lesbiese ouers verantwoordelikheid vir ouerskap aanvaar het, huishoudelike pligte eweredig verdeel het en kwaliteit verhoudinge met die adolessente gehandhaaf het. Hierdie adolessente kon die uitdagings vanuit die sosiale konteks beter hanteer en gevoelens van verwerping en minderwaardigheid die hoof bied; derhalwe beskou hulle hul persoonlike groei ook as 'n positiewe aspek van hul lesbiese ouerhuis. Hulle is minder bevooroordeeld en toon openheid en respek vir ander persone se oortuigings, waardes en besluite.

Die adolessente wie se lesbiese ouers gelowig is, het ook positiewe gesinservarings gehad en het veilig gevoel in die wete dat hul ouers op God vertrou. Die adolessente het geloof in Christus deurentyd hoog op prys gestel en as die sin en rigtingwyser van die lewe beskou.

\section{Negatiewe aspekte van die lesbiese gesin wat die adolessente se sin vir self kan belemmer}

Hoewel die meeste literatuur fokus op die positiewe uitkomste van lesbiese ouerskap, blyk daar besliste uitdagings binne lesbiese ouerhuise te wees. Die empiriese resultate van die navorsing het die adolessente se vrees vir homofobie, verwerping en stigmatisering, as gevolg van hul ouers se seksuele oriëntasie, as die belangrikste negatiewe aspek van lesbiese gesinne aangedui. Hoewel dit vanuit die internasionale literatuuroorsig blyk dat daar 'n groter openheid in die samelewing teenoor homoseksuele persone ontwikkel het, ondervind die meerderheid adolessente wat aan die navorsing deelgeneem het steeds skuldgevoelens, vrees vir verwerping, eensaamheid en gevoelens van andersheid binne die Suid-Afrikaanse konteks. Die emosionele belewenisse van hul lesbiese ouers omsluit die adolessente wat in hierdie huise grootword, en derhalwe ervaar die adolessente intense vrees dat hul gesinsidentiteit bekend sal word en dit daartoe sal lei dat hulle deur hul portuurgroep en ander belangrike persone vanuit die sosiale omgewing verwerp sal word. Hul vrees vir verwerping gee ook aanleiding vir die ervaring van botsende emosies, soos byvoorbeeld somtyds innerlike woede vir die veroordeling vanuit die samelewing, gevoelens van hopeloosheid omdat hulle nie die siening van ander in verband met homoseksualiteit kan verander nie en spanning as gevolg van die geheimhouding van hul gesinsidentiteit. Dit is belangrik om in gedagte te hou dat vrees vir stigmatisering en verwerping alle aspekte van die adolessente se lewe beïnvloed en dus ook die ontwikkeling van hul sin vir self stremmend kan beïnvloed.

Konflik tussen die lesbiese metgesel ouer en die adolessente blyk ook 'n struikelblok in die adolessente se aanvaarding van die lesbiese ouerhuis te wees, en lei tot verhoogde spanning in die gesinsverhoudinge. Hierdie konflik laat adolessente onttrek uit gesinsaktiwiteite en wek gevoelens van eensaamheid, frustrasie en onbevoegdheid. Hul botsende emosies ten opsigte van die lesbiese metgesel ouer laat die adolessente soms voel asof hulle hul biologiese ma verraai.

In die gesinne waar finansiële tekorte beleef word as gevolg van die werkloosheid van een van die ouers, ervaar die 
adolessente gevoelens van onsekerheid oor die toekoms, spanning en minderwaardigheid. Hulle idealiseer gesinne waar daar aan al die materiële behoeftes voorsien kan word en hulle beskou die afwesigheid van 'n vaderfiguur in hul gesinne as 'n oorsaak vir die finansiële tekorte. Uit die empiriese navorsing blyk die afwesigheid van 'n vaderfiguur ook 'n negatiewe aspek van lesbiese ouerskap te wees. Dit was veral die adolessente seuns wat 'n pa-seun-verhouding begeer het. Hulle het die afwesigheid van 'n vaderfiguur as 'n groot verlies ervaar.

Die negatiewe aspekte van 'n lesbiese ouerhuis, soos blyk uit die empiriese resultate van die navorsing, hou verband met die adolessente se ontwikkeling van 'n gesonde sin vir self, en derhalwe moet ouers en pastorale beraders hulle daarvan vergewis ten einde hulp te kan verleen aan adolessente wat in lesbiese ouerhuise grootword.

\section{Hulpverlening God se verhaal}

Binne die pastoraat is dit noodsaaklik dat beraders sal onthou dat God se verhaal, wat in Jesus Christus ontvou, nie eksklusief van aard is nie, maar in alle opsigte inklusief, soos voorgehou in Johannes 3:16:

Want so lief het God die wêreld gehad, dat Hy sy eniggebore Seun gegee het, sodat elkeen wat in Hom glo, nie verlore mag gaan nie, maar die ewige lewe sal hê.

Adolessente wat stigmatisering en verwerping ervaar het, as gevolg van hul lesbiese ouers se seksuele oriëntasie, moet gewoonlik negatiewe emosies soos hartseer, pyn en eensaamheid verwerk. Hulle kan selfs voel dat God hulle in die steek gelaat het. Dit is juis hier waar pastorale beraders die verantwoordelikheid moet neem om die adolessente te begelei om te ontdek dat God hulle nie verwerp nie, maar insluit in Sy verhaal van liefde, vergifnis, genade en nuwe lewe (Mostert 2011:67).

Bo die mens en om die mens skryf God 'n groter verhaal; een wat deur Sy wil gevorm word en volgens Sy kalender ontvou. Dit is juis in die lig van God se verhaal wat die pastorale berader die adolessente en hul ouers kan begelei om hul eie verhale te herinterpreteer en nuwe perspektief in die sin van die lewe te vind. God se verhaal is 'n sensitiewe en beskrywende verhaal wat elke mens die versekering bied dat, ongeag wat die inhoud van hul huidige lewensverhale mag wees, God elke mens by Sy verhaal van genade en versoening insluit (Bennett 2011:139). In Jeremia 29:11 verklaar Hy onomwonde: 'want ek weet watter gedagtes ek aangaande julle koester, spreek die Here, gedagtes van vrede en nie van onheil nie, om julle 'n hoopvolle toekoms te gee'.

Vanuit die navorsing blyk dit dat die pastorale berader juis binne die konteks van God se verhaal die belangrikheid van die adolessente se persoonlike keuse ten opsigte van Jesus Christus kan verduidelik. Hierdie keuse berus op 'n geloofsbesluit om Jesus Christus as die Seun van God sentraal te stel in elke opsig van die lewe. Jesus Christus word dan die middelpunt waaruit die mens se gedagtes oor God en die mens, oor die verhouding van God met die mense, oor die heil van die mens en die wêreld, oor sedelikheid, moraliteit en die sin van die lewe gerig word. Deur die Heilige Gees word mense getransformeer op 'n wyse wat net God kan bewerk (Collins 2005:180). Hierdie transformasie vind plaas wanneer mense in geloof tot handeling oorgaan en Jesus Christus as Verlosser en Saligmaker aanvaar en daardeur met God versoen word. Die versoende mens is in Christus 'n nuwe skepping, nie alleen is sy of haar sonde vergewe nie, maar is hy of sy ook onder die heerskappy van Christus gebring, en dit word deur sy of haar ganse lewe sigbaar. Paulus verduidelik hierdie nuwe lewe in Galasiërs 2:20 soos volg: 'Ek is met Christus gekruisig en ek leef nie meer nie, maar Christus leef in my'. Die gelowige se lewe word dus nie alleen gerig deur persoonlike kwaliteite, bekwaamheid en vermoëns nie, maar deur die gawe van die Heilige Gees kan die gelowige oorwinnend leef.

Die adolessente in 'n lesbiese ouerhuis se keuse vir Jesus Christus kan hulle ontwikkeling van 'n sin vir self en hul vestiging van 'n persoonlike identiteit in alle opsigte raak. Namate hul geloofsverhouding groei en hul kennis aangaande die Vader, die Seun en die Heilige Gees uitbrei, sal hul sin vir self geskoei word op God se plan vir hul lewens wat deur die inwoning en teenwoordigheid van die Heilige Gees in hul lewens sigbaar word. Geloof word op hierdie wyse die bril waardeur hulle na die lewe kyk, en dan alleen word omstandighede, teleurstellings en uitdagings in 'n nuwe perspektief geplaas. 'n Perspektief wat die totale lewe benader vanuit die geloofsoortuiging soos Paulus dit in Filippense 4:13 verwoord: 'Ek is tot alles in staat deur Christus wat my die krag gee.'

\section{Gestaltperspektief}

Vanuit 'n Gestaltperspektief word persoonlike groei en gesonde ontwikkeling moontlik wanneer 'n persoon se bewustheid in die hier en nou op so 'n wyse plaasvind dat die persoon in staat is om selfregulerend op te tree (Joyce \& Sills 2006:37; Clarkson 2004:22). Organismiese selfregulering vind plaas wanneer 'n persoon oor die vermoë beskik om persoonlike behoeftes suksesvol te bevredig, wat vanuit die persoon self of vanuit die fenomeenveld ontwikkel. Wanneer 'n behoefte suksesvol bevredig is, word die gestalt voltooi en ervaar 'n persoon 'n gevoel van genoegdoening en tevredenheid met die self en die omgewing of veld (Clarkson 2004:23; Korb, Gorrel \& Van de Riet 1989:37).

Adolessente het volgens Blom (2004:114) twee basiese behoeftes wat bevrediging vereis om persoonlike groei te stimuleer en die ontwikkeling van 'n gesonde sin vir self moontlik te maak, ten einde 'n persoonlike identiteit te bereik. Hierdie basiese behoeftes is eerstens 'n behoefte aan onvoorwaardelike liefde en aanvaarding, en tweedens die behoefte aan 'n gevoel van bevoegdheid. Vanuit die fenomeenveld word die bevrediging van 
behoeftes in die lewens van adolessente in lesbiese ouerhuise gestrem as gevolg van bepaalde uitdagings en struikelblokke. Die grootste uitdaging binne hul gesinne is vir sommige adolessente die konflik met die metgesel ouer wat hul bevoegdheid in twyfel trek en gevoelens van minderwaardigheid, onttrekking, onbekwaamheid en alleenheid tot gevolg het. Die afwesigheid van 'n vaderfiguur, word veral deur die adolessente seuns as 'n leemte ervaar, wat daartoe aanleiding gee dat hulle onvergenoegdheid met hul huidige omstandighede beleef en 'n voortdurende verlange na 'n pa ervaar.

Vanuit die wyer sosiale konteks en fenomeenveld, ervaar adolessente uit lesbiese ouerhuise ook voortdurend stigmatisering, etikettering en verwerping as gevolg van hul ouers se seksuele oriëntasie. Dit gee aanleiding tot uiteenlopende emosionele ervarings wat wissel van gevoelens van aggressie, verwyt en opstandigheid teenoor die sosiale konteks en selfs teenoor God, gevoelens van moedeloosheid, minderwaardigheid, angs en onsekerheid. Hierdie uitdagings bedreig die bevrediging van die adolessente in lesbiese ouerhuise se behoeftes aan onvoorwaardelike liefde en aanvaarding en het ' $n$ invloed op die gesonde ontwikkeling van hulle sin vir self om behoeftebevrediging te bewerkstellig. Die onafgehandelde en onbevredigende behoeftes in die ervaringsveld verhinder dat die adolessente effektiewe selfregulering kan toepas en 'n voltooide gestalt kan bereik.

Vanweë die kompleksiteit van die uitdagings wat die navorsing uitwys kan 'n holistiese mensbeskouing alleenlik plaasvind wanneer die adolessente vanuit sowel hul natuurlike veld as hul spirituele veld benader word.

Binne die natuurlike veld word die adolessente voortdurend gekonfronteer met gebrokenheid, tekorte, onbevredigde behoeftes, spanning en konflik. Konflik met die metgesel ouer kan moontlik aangespreek word deur middel van pastorale berading en hulpverlening, maar stigmatisering, spot en verwerping, asook die afwesigheid van 'n vaderfiguur, is uitdagings wat moeilik verantwoordbaar is. Verandering binne die natuurlike veld is dikwels moeilik bereikbaar en onderhewig aan verskeie veranderlikes wat moeilik voorspelbaar is, derhalwe toon die navorsing dat die innerlike, spirituele ingesteldheid van die adolessente ' $n$ groter bepaler van persoonlike groei en ontwikkeling is.

Die adolessente se behoefte aan onvoorwaardelike liefde en aanvaarding kan bevrediging vind, nie net om die gestalt in die natuurlike veld te voltooi nie, maar in die spirituele ervaring van God se ewige, onvoorwaardelike liefde vir die mens. Waar die mens in die natuurlike fenomeenveld moet staatmaak op persoonlike sterktes en eksterne ondersteuning om behoeftebevrediging te verwesenlik, verskuif die klem binne die spirituele veld na 'n geloofsverhouding met God. Dit omsluit die transendente werklikheid dat die gesonde ontwikkeling van 'n sin vir self nie primêr in die mens gesetel is nie, maar in die almag van God. In die hier en nou vind daar ' $n$ verandering in terme van die hantering van uitdagings, soos die spot en stigmatisering waarmee die adolessente gekonfronteer word, plaas. Waar die adolessente se sin vir self beïnloed is deur sowel hul selfbeskouing as die mening en opinie van ander mense uit die sosiale omgewing, word dit eerder getransformeer deur God se liefde en teenwoordigheid in hul lewens. Selfregulering binne die spirituele veld vanuit die Christelike geloof verkry hierdeur 'n nuwe betekenis. 'n Voltooide gestalt kom tot stand wanneer die self toelaat dat selfregulering deur die transformerende werking van die Heilige Gees in emosies, denke en gedrag (totale mens) bewerk word ten einde behoeftes te bevredig. Op hierdie wyse word die adolessente se diepste behoefte aan onvoorwaardelike liefde en aanvaarding binne die spirituele veld bevredig deur ' $n$ geloofsverhouding met God en die bewustheid van God se ewige, onvoorwaardelike liefde.

\section{Samevatting}

Vanuit die empiriese resultate van hierdie studie kan daar hulp verleen word aan lesbiese ouers, om adolessente te help in die gesonde ontwikkeling van 'n sin vir self binne die unieke gesinsdinamika van 'n lesbiese gesin. In die lig hiervan, het die navorser aanbevelings en riglyne saamgestel om aan ouers en pastorale beraders hulp te verleen in die begeleiding van adolessente binne 'n lesbiese ouerhuis:

- Tydens die hulpverleningsproses moet daar deurentyd 'n bewustheid wees van die adolessente se primêre behoeftes naamlik, hul behoefte aan liefde en aanvaarding asook hul behoefte aan 'n gevoel van bevoegdheid. Hierdie behoeftes kan bevredig word wanneer die adolessente geleentheid gebied word om hulself te definieer sonder enige vrees dat hulle aan antagonisme, stigmatisering, verwerping en homofobie blootgestel sal word.

- Die adolessente se vermoë om hulself te beskryf en te definieer speel 'n belangrike rol in die verhoging van hul selfbewustheid en die ontwikkeling van hul sin vir self. Dit is ook noodsaaklik om binne die gesins- en beradingsverhoudings aan die adolessente die geleentheid te bied om hul eie opinies, gedagtes en waarnemings te deel asook om hul eie keuses uit te oefen in besluitnemingsprosesse. Dit sal die adolessente se gevoel van bevoegdheid en selfwaarde verhoog, wat noodsaaklik is vir die ontwikkeling van 'n sin vir self.

- Diegesins-enberadingsverhoudingsmoetplaasvindbinne duidelik gedefinieerde grense, wat aan die adolessente sekuriteit en veiligheid bied sodat hulle gemaklik kan wees om hul ware self te openbaar. Die wyse van kommunikasie en interaksie speel 'n deurslaggewende rol in die gesins- en beradingsverhoudings. Vriendelikheid, gemaklikheid, empatie, aanvaarding, respek, humor en onvoorwaardelike liefde sal 'n gevoel van veiligheid skep waarin die adolessente kan eksperimenteer, oefen en verander om 'n gesonde sin vir self te ontwikkel en 'n persoonlike identiteit te bereik. 'n Veilige omgewing 
kan alleenlik geskep word wanneer beide ouers in die lesbiese ouerhuis bereid is om hulself oop te stel en met oorgawe aan die interaksies deel te neem ten einde kwaliteit verhoudings te vestig.

In die lig hiervan is die navorser van mening dat riglyne en aanbevelings met die regte gesindheid geïnspireer en aanbeveel moet word. Die navorser stem saam met Müller (2006:4) dat daar dikwels konstrukte van mense gevorm word wat moet inpas by antieke teorieë en voorveronderstellings. In so 'n handelswyse kan geen verandering gefasiliteer word nie, omdat ware verandering heel eerste by die self begin.

Hierdie navorsingsreis het die navorser opnuut laat besef hoe ondeurdringbaar persoonlike grense kan wees as gevolg van onkunde, wanpersepsies en vooropgestelde idees. Ware verandering, ondersteuning en hulpverlening kan net geskied as grense tussen mense oorgesteek word om mekaar in liefde te aanvaar. In hierdie lig kan teologie wegbeweeg van 'n lineêre benadering waarin mense voorgeskryf word oor hoe hulle oor hulself, die lewe en God moet nadink en eerder van 'n skakelbord-teologie gebruik moet maak, wat Müller (2006) soos volg voorstel:

Volgens hierdie metafoor is teologie nie veronderstel om antwoorde te verskaf nie, maar om 'n konneksie te bewerk tussen 'n verskeidenheid van verhale: Die verhale van die individu, die gesin en familie, die gemeenskap en ook die fundamentele verhaal van die Christelike geloofsgemeenskap. (bl. 3)

Wat van belang is, is dat die groter verhaal van God nooit afgewater mag word om aan te pas by die mens se begrensde en beperkte milieu nie. Die verhaal van Jesus Christus is 'n revolusionêre verhaal, wat nie by tye of geleenthede aanpas nie, maar wat mense, tye en geleenthede uitdaag om by Hom aan te pas. Vanuit dié vertrekpunt word die pastorale berader 'n skakelbeampte wat help om hulpverlening aan adolessente se soeke na die self binne 'n lesbiese ouerhuis te bewerk, maar wat absoluut verlaat is op die werking van die Heilige Gees om al die nodige herstel, genesing en verandering te bewerk. Hierdeur word die sin van die lewe nie langer gevind in die bevrediging van persoonlike behoeftes in die hier en nou nie, maar in die roeping en doel van God, naamlik om deur die Heilige Gees medewerker te word binne die koninkryk van God.

\section{Erkenning}

\section{Mededingende belange}

Die outeurs verklaar dat hulle geen finansiële of persoonlike verbintenis het met enige party wat hulle nadelig of voordelig kon beïnvloed in die skryf van hierdie artikel nie.

\section{Outeurs bydraes}

B.v.d.V. (Noordwes-Universiteit) het hierdie artikel geskyf onder die toesig van R.A.D. (Noordwes-Universiteit) en H.B.G. (Noordwes-Universiteit).

\section{Literatuurverwysings}

Amoateng, A.Y., Richter, L.M., Makiwane, M. \& Rama, S., 2004, 'Describing the structure and needs of families in South Africa: Towards the development of a national policy framework for families', Report commissioned by the Dept of Social Development, Child, Youth and Family Development, Human Sciences Research Council, Pretoria, viewed 15 June 2013, from http://www.hsrc.ac.za/en/ research-outputs/view/1831

Anthonissen, C. \& Oberhozer, P., 2001, Gelowig en gay? Riglyne vir'n sinvolle dialoog met gay-lidmate, Lux Verbi, Wellington.

Balswick, J.O. \& Balswick, J.K., 2006, The family a Christian perspective on the contempary home, Baker Publishing Group, Grand Rapids.

Barna, G., 2011a, Futurecast: What today's trends mean for tomorrow's world, Tyndale House Publishers, Austin.

Barna, G., 2011b, Revolutionary parenting, Christian Art Publishers, Vereeninging.

Bennett, D.J., 2011, A passion for the fatherless, Kregel Publications, Grand Rapids.

Berger, K.S., 2011, The developing person through the life span, Worth Publishers, New York

Berk, L.E., 2012, Infants, children and adolescents, 7th edn., Allyn \& Bacon, Boston.

Beyers, C., 2005, 'Die gevolge van positiewe MIV-diagnosering by adolessente-leerders', PhD proefskrif, Dept. Sielkunde, Universiteit van die Vrystaat, Bloemfontein.

Blom, R., 2004, Handbook of Gestalt play therapy, Drufoma, Bloemfontein.

Bosacki, S.L., 2001, 'Spirituality, gendered subjectives and education in preadolescents: Canadian preadolescents' reflections on gender-roles and their sense of self', International Journal of Children's Spirituality 6(2), 207-219.

Bosacki, S.L. \& Ota, C.,2000, 'Pre-adolescents voices: A consideration of British and Canadian children's reflections on religion, spirituality and their sense of self', International Journal of Children's Spirituality 5(2), 204-217.

Boshoff, L., 2002, 'Die verband tussen humorsin en psigologiese welstand by adolessente', PhD proefskrif, Departement Sielkunde, Universiteit van die Vrystaat, Bloemfontein.

Clarkson, P., 2004, Gestalt counseling in action, 3rd edn., SAGE Publications, London.

Coleman, J. \& Hagell, A., 2007, Adolescence, risk and resilience against the odds, John Wiley \& Sons, New York.

Collins, G.R., 2005, Die a tot z van berading, Struik Christelike Boeke, Kaapstad.

De Villiers, G., 2007, Die huwelik as instelling van God, met implikasie vir gay-huwelike, Phd proefskrif, Dept. Praktiese Teologie, Universiteit van Pretoria, Pretoria.

Dreyer, A.E., 2007, "n Krities-hermeneutiese perspektief op die huwelik in 'n postmoderne era', MTh skripsie, Dept. Praktiese Teologie, Universiteit van Pretoria, Pretoria.

Dreyer, T.F.J., 2008, Die kerk, die huwelik en seks - 'n morele krisis?, PhD proefskrif, Dept. Praktiese Teologie, Universiteit van Pretoria, Pretoria.

Du Plessis, J.C., 2009, 'Heling van die familie: Ondersoek na pastorale dimensies van die liturgie', PhD proefskrif, Dept. Praktiese Teologie en Missiologie, Universiteit van Stellenbosch.

Ebersohn, H., 2001, 'Die verband tussen kreatiewe denke en psigologiese weerbaarheid by kinders in hul laat middelkinderjare', MSc verhandeling, Departement Sielkunde, Universiteit van die Vrystaat, Bloemfontein.

Erikson, E.H., 1982, Identity, youth and crisis, Norton, New York.

Henderson, D.A. \& Thompson, C.L., 2011, Counseling children, 8th edn., International Edition, Brooks Cole, Belmont.

Horak, G.C., 2005, Homoseksualisme: Probleem of simptoom?, Dupla Drukkers, Bloemfontein.

Impett, E.A., Sorsoli, L., Schooler, D., Henson, J.M. \& Tolman, D.L., 2008, 'Girls' relationship authenticity and self-esteem across adolescence', Developmental Psychology 44(3), 722-733.

Johnson, S.M. \& O'Connor, E., 2001, For lesbian parents, The Guilford Press, New York.

Jordaan, A., 2005, 'Pastorale terapie vanuit die vadermetafoor aan kliënte met veralgemeende angstversteuring', PhD proefskrif, Dept. Praktiese Teologie, Universiteit van die Vrystaat, Bloemfontein.

Joubert, S., 2009, Jesus 'n radikale sprong, Christelike Uitgewersmaatskappy, Vereeniging.

Joyce, P. \& Sills, C., 2006, Skills in Gestalt counseling and psychotherapy, Sage Publications, London.

Kiesling, C., Sorell, G.T., Montgomery, M.J. \& Colwell, R.K., 2006, 'Identity research and psychosicial formation of one's spiritual sense of self: Implications for religious educators and Christian institutions of higher education', Christian Education Journal 3(2), 255-257.

Korb, M.P., Gorrel, J. \& Van de Riet, V., 1989, Gestalt therapy practice and theory, 2nd edn., Pergamon Press, New York.

Kottak, C.P., 2008, Anthropology: The exploration of human diversity, 12th edn., McGraw-Hill, Singapore.

Kottak, C.P., 2010, Window on humanity, 4th edn., McGraw-Hill, New York.

Lamanna, M.A. \& Riedmann, A., 2009, Marriages and families: Making choices in a diverse society, 12th edn., Thomson Learning, Belmont.

Larney, T., 2009, 'Die gesin as primêre geloofseenheid in 'n postmoderne konteks: 'n Pastorale studie', PhD proefskrif, Dept. Praktiese Teologie, Noordwes-Universiteit, Potchefstroom. 
Louw, D.A., Van Ede, D.M. \& Louw, A.E., 2004, Menslike ontwikkeling, 3de uitg., Kagiso, Pretoria.

Louw, D.J., 2005, Mechanics of the human soul: About maturity and life skills, Sun Press, Stellenbosch.

Manning, M.A., 2007, 'Self-concept and self-esteem in adolescents', viewed 15 Augus 2013, from http://www.naspcenter.org/principals

Maré, C., 1996, 'Gesinspolitiek en die Ouer-Kind verhouding', LLM verhandeling, Dept. Regsgeleerdheid, Noord-Wes Universiteit, Potchefstroom.

Marks, L., 2012, 'Same-sex parenting and children's outcomes: A closer examination of the American psychological association's brief on lesbian and gay parenting', Journal of Social Science Research 41, 735-751. http://dx.doi.org/10.1016/j. ssresearch.2012.03.006

Mostert, J., 2011, How to become HIV+ guidelines for the local church, Kerus Global Education, Johannesburg.

Müller, J., 2002, Gesinne van binne, CLF-Drukkers, Bloemfontein.

Müller, J., 2006, 'Lente in die teologie', Beeld Plus 4, 23 Augustus, bl. 4.

Neff, K.D. \& McGehee, P., 2009, 'Self-compassion and psycological resilience among adolescents and young adults', Self and Identity 9, 225-240. http://dx.doi. org/10.1080/15298860902979307

Oaklander, V., 1988, Windows to our children: A Gestalt therapy approach to children and adolescents, The Gestalt Journal Press, Gouldsboro.

Omoto, A.M. \& Kurtzman, H.S., 2006, Sexual orientation and mental health: Examining identity and development in lesbian, gay and bisexual people, American Psychological Association, Washington. http://dx.doi.org/10.1037/11261-000

Oswald, R.F. \& Kuvalanka, K., 2008, 'Same-sex couples: Legal complexitities', Journal of Family Issues 29(8), 1051-1066.

Peacock, R. \& Theron, A., 2007, 'Identity development of the incarcerated adolescent with partcular reference to prison gang membership', Acta Criminologica 20(3), 61-74.

Perlesz, A. \& McNair, R., 2004, 'Lesbian parenting: Insiders' voices', Anzjft 25(2), 129-140.

Pienaar, J.M., 2002, 'Die verband tussen konserwatisme en psigologiese welstand by adolessente', PhD proefskrif, Dept. Sielkunde, Universiteit van die Vrystaat, Bloemfontein

Pleck, J.H. \& Masciadrelli, B.P., 2004, 'Paternal involvement by U.S. residential fathers: Levels, sources and consequences', in M.E. Lamb (ed.), The role of the father in child development, pp. 222-271, John Wiley \& Sons, Hoboken.

Robitaille, C. \& Saint-Jacqeus, M., 2009, 'Social stigma and the situation of young people in lesbian and gay stepfamilies', Journal of Homosexuality 56(4), 421-442. http://dx.doi.org/10.1080/00918360902821429

Shaffer, D.R. \& Kipp, K., 2007, Developmental psychology, childhood \& adolescence, 7th edn., Thomson Wadsworth Publishers, Belmont.
Sigelman, C.K. \& Rider, E.A., 2009, Life-span human development, 6th edn., Wadsworth Cengage Learning, Belmont.

Stanton, G.T. \& Maier, B., 2005, Die huwelik in die spervuur, Christelike Uitgewersmaatskappy, Vereeniging.

Stoop, D., 2004, Making peace with your father, Regal, Ventura.

Strong, B., De Vault, C. \& Cohen, T.F., 2011, The marriage and family experience, Wadsworth Cengage Learning, Belmont.

Strydom, Z.R.A., 2001, 'Die belangrikheid van die gesin in die gemeentelike bediening', PhD proefskrif, Dept. Praktiese Teologie, Universiteit van Suid-Afrika, Pretoria.

Švab, A., 2007, 'New ways of parenting: Fatherhood and parenthood in lesbian families', Revija Za Sociologiju 38(1/2), 43-55.

Taljaard, A. \& Langner, D., 2013, "n Foto van Afrikaanse gesinne', Solidariteit helpende hand, bl. 1-18, besigtig 10 September 2013, by http://helpendehand.co.za/wpcontent/uploads/dokumente/FINALE\%20GESINSVERSLAG.pdf

Tasker, F. \& Patterson, C., 2007, 'Research on gay and lesbian parenting', Journal of GLBT Family Studies 3(2/3), 9-34. http://dx.doi.org/10.1300/J461v03n02_02

Telingator, C.J. \& Patterson, C., 2008, 'Children and adolescents of lesbian and gay parents', Child and Adolescent Psychiatry 47(12), 1364-1368. http://dx.doi. org/10.1097/CHI.0b013e31818960bc

Thatcher, A., 2007, Theology and families, Blackwell Publishing, Oxford. http://dx.doi. org/10.1002/9780470776681

Van Gelderen, L., 2012, 'Adolescents in planned lesbian families in the U.S. and the Netherlands: Stigmatization, psychological adjustment and resilience', pp. 1-136, viewed 22 August 2013, from http://dare.uva.nl/record/431836

Van Niekerk, E., 2005, "n Teologiese perspektief op die moderne problematiek van die man as die afwesige pa', MTh verhandeling, Dept. Praktiese Teologie, Universiteit van Johannesburg.

Van Wyk, D.J.C., 2002, 'Die huwelik en seksualiteit in 'n postmoderne samelewing', HTS Teologiese Studies/Theological Studies 58(1), 264-282. http://dx.doi. org/10.4102/hts.v58i1.537

Van Wyk, H., 2011, 'Die verband tussen weerbaarheidsfaktore en lewenstevredenheid by adolessente: 'n Kruiskulturele studie', MSocSc verhandeling, Dept. Sielkunde, Universiteit van die Vrystaat, Bloemfontein.

Warnke, G., 2007, After identity: Rethinking race, sex and gender, Cambridge University Press, Cambridge.

Whitney-Thomas, J. \& Moloney, M., 2001, “Who I am and what I want': Adolescents' self-definition and struggles', Exceptional Children 67(3), 375-389.

Wogaman, J.P., 2009, Moral dilemmas, Westminster John Knox Press, Louisville.

Woodward, K., 2002, Understanding identity, Hodder Education, London. 